\title{
Correction to: How to measure blood pressure using an arterial catheter: a systematic 5-step approach
}

Bernd Saugel ${ }^{1,2^{*}}$, Karim Kouz $^{1 \dagger}$, Agnes S. Meidert ${ }^{3}$, Leonie Schulte-Uentrop ${ }^{1}$ and Stefano Romagnoli ${ }^{4,5}$

\section{Correction to: Crit Care (2020) 24:172}

https://doi.org/10.1186/s13054-020-02859-w

In the publication of this article [1], there was an error in Fig. 4. The arrow indicating the amplitude $A_{1}$ was too short and therefore did not cover the correct amplitude of the waveform.

The correct figure is:

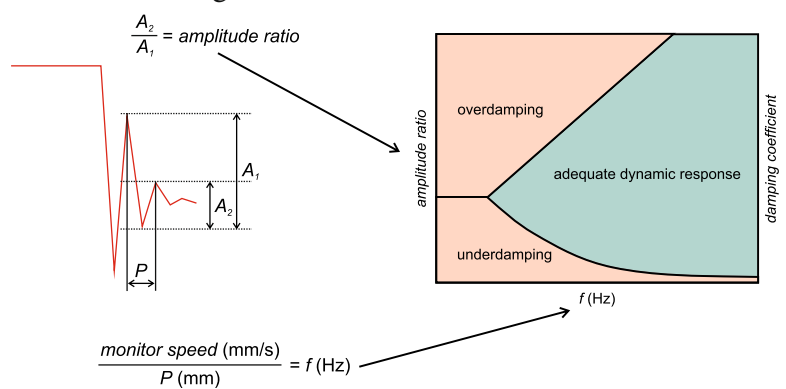

\section{Author details}

'Department of Anesthesiology, Center of Anesthesiology and Intensive Care Medicine, University Medical Center Hamburg-Eppendorf, Martinistrasse 52, 20246 Hamburg, Germany. ${ }^{2}$ Outcomes Research Consortium, Cleveland, OH, USA. ${ }^{3}$ Department of Anaesthesiology, University Hospital LMU Munich, Munich, Germany. ${ }^{4}$ Department of Health Science, Section of Anesthesia and Critical Care, University of Florence, Florence, Italy. ${ }^{5}$ Department of Anesthesia and Critical Care, Azienda Ospedaliero-Universitaria Careggi, Florence, Italy.
Published online: 23 June 2020

\section{Reference}

1. Saugel B, Kouz K, Meidert A, et al. How to measure blood pressure using an arterial catheter: a systematic 5-step approach. Crit Care. 2020;24:172 https:// doi.org/10.1186/s13054-020-02859-w.

The original article can be found online at https://doi.org/10.1186/s13054020-02859-w.

*Correspondence: bernd.saugel@gmx.de; b.saugel@uke.de

${ }^{\dagger}$ Bernd Saugel and Karim Kouz contributed equally to this work.

'Department of Anesthesiology, Center of Anesthesiology and Intensive Care Medicine, University Medical Center Hamburg-Eppendorf, Martinistrasse 52,

20246 Hamburg, Germany

${ }^{2}$ Outcomes Research Consortium, Cleveland, OH, USA

(c) The Author(s). 2020 Open Access This article is licensed under a Creative Commons Attribution 4.0 International License, which permits use, sharing, adaptation, distribution and reproduction in any medium or format, as long as you give appropriate credit to the original author(s) and the source, provide a link to the Creative Commons licence, and indicate if changes were made. The images or other third party material in this article are included in the article's Creative Commons licence, unless indicated otherwise in a credit line to the material. If material is not included in the article's Creative Commons licence and your intended use is not permitted by statutory regulation or exceeds the permitted use, you will need to obtain permission directly from the copyright holder. To view a copy of this licence, visit http://creativecommons.org/licenses/by/4.0/. The Creative Commons Public Domain Dedication waiver (http://creativecommons.org/publicdomain/zero/1.0/) applies to the data made available in this article, unless otherwise stated in a credit line to the data. 